\title{
ANTI-INFLAMMATORY ACTIVITY OF PHARMACEUTICAL GEL OF ETHANOLIC EXTRACT FROM MARINE SPONGE Xestospongia $S P$
}

\author{
Wa Ode Sitti Zubaydah \\ Wahyuni \\ Sahidin \\ Tian Amalia Halik \\ Rina Andriani \\ Astrid Indalifiany \\ Adryan Fristiohady* \\ Universitas Halu Oleo, Kendari, \\ Southeast Sulawesi, Indonesia \\ email: adryanfristiohady@uho.ac.id
}

Keywords:

Gel

Ethanol extract

Xestospongia Sp. sponge

Carrageenan

Anti-inflammatory

\begin{abstract}
The aim of this study was to determine the characteristics of the gel formula based on it's organoleptic properties, $\mathrm{pH}$, viscosity, dispersion and homogeneity by stability test carried out using the cycling test method and to determine the anti-inflammatory activity of the Xestospongia Sp. in male white mice (Mus musculus) by creating an artificial edema on the mice left foot induced by $1 \% \lambda$-carrageenan. The gel formula from the ethanol extract of Xestospongia Sp. sponge was physically stable in terms of its organoleptic observation, homogeneity, $\mathrm{pH}$ and viscosity test. However, the results that were obtained after dispersion test did not fulfill the requirements. In this study, the gel formula of the ethanol extract of Xestospongia Sp. sponge was administered on the mice left foot by using the variations in extract concentration of $0.02 \%, 0.03 \%$, and $0.04 \%$, and the gel without extract as a negative control and Galtaren ${ }^{\circledR g e l}$ ( $1 \%$ Diclofenac Sodium) as a positive control. The evaluated data were in the form of mice leg edema volume measured based on its percent of inflammation and percent of inflammatory inhibition and observed for 360 minutes. The data were analyzed by using the Kruskal-Wallis test followed by the Mann-Whitney test with a confidence level of $95 \%$. The results of this study showed that the gel formula of ethanol extract of Xestospongia Sp. sponge has an anti-inflammatory effect on each concentration, and the formula that has a large anti-inflammatory effect was obtained at extract concentration of $0.04 \%$.
\end{abstract} Palangkaraya. This is Open Access article under the CC-BY-SA License (http://creativecommons.org/licenses/by-sa/4.0/). DOI: https://doi.org/l0.33084/bjop.v2il.694.

\section{INTRODUCTION}

Indonesia is the largest archipelago country in the world and has a beach length of $81,000 \mathrm{~km}$ which is rich in coral reefs and other marine biota. Since the 1980s, the attention of the world of medicine has been directed towards marine biota as a potential resource. Some marine biota that are known to produce active compounds include sponges, molluscs, Bryozoa, tunicata and others (Cribb \& Ford, 2009). One of the marine biota that is currently being studied is sponges. Sponges are one of the components of the composition of coral reefs that have the potential of bioactive compounds that have not been widely used (Mehbub et al., 2014).

The sponge consists of three main classes, namely Calcarea, Demospongiae, and Hexactinellidae. The Demospongiae class is a sponge group that dominates more than $90 \%$ of sponge species (Marzuki, 2018). One species of this class that can be used as a medicinal ingredient is Xestospongia Sp. which is known to have various activities such as anticancer (Murniasih, 2003), antiplasmodial, antibiotic, antifungal, cardiotonic, cytotoxic, and antimalarial (Sadarun et al., 2018).

The study conducted by El-Shytany et al (2015) reported that methanol extract from Xestospongia sponge showed an anti-inflammatory effect that is thought to originate from the content of sterol compounds on sponges. Based on research conducted by Amri (20l8), it was shown that the ethanol extract of Xestospongia sp. has anti-inflammatory ability which was measured using the red blood cell stabilization method with the stability percentage of the ethanol extract of Xestospongia Sp. at 50 ppm (56\%), 100 ppm (67\%), 200 ppm (69\%), 400 ppm (76\%), 800 ppm (83\%), 1600 ppm (87\%) and 3200 ppm (88\%) and categorized 
as toxic with an $\mathrm{LC}_{50}$ value of 440.53 ppm for Artemia salina Leach.

Inflammation is the body's attempt to inactivate or damage organisms that attack, eliminate and regulate the degree of tissue repair (Wijaya et al., 2015). The inflammatory response is characterized by conditions such as redness, heat, pain, swelling and dysfunction (Sukmawati, 2015). Anti-inflammatory drugs commonly used are divided into two, namely steroid antiinflammatory and non-steroidal anti-inflammatory drugs (NSAIDs) (Widiyantoro et al., 20I2). Both of these groups can relieve inflammatory reactions well but long-term use can have side effects (Hardman \& Limbird, 2003). Based on this, there is a lot of development of anti-inflammatory products derived from natural ingredients and replacing routes through topical drug administration.

One of the topical dosage forms is gel. Gel is a semisolid system made of small inorganic particles or large organic molecules penetrated by a liquid. Gel has the ability to spread well on the skin, easily dries, forms a film that is easy to wash and gives a cool feeling to the skin (Sayuti, 2015).

Based on the description above, the authors conducted a study to make anti-inflammatory gel preparations from Xestospongia Sp. Organoleptic observations will include the shape, color, and smell of the preparation during a certain storage time, followed by testing homogeneity, $\mathrm{pH}$, dispersion, and viscosity of the preparation, and then testing the anti-inflammatory effects of gel preparations made on white male mice.

\section{MATERIAL AND METHODS}

\section{Tools and Materials}

The tools used in this study include beaker (Pyrex®), measuring cups (Pyrex®), hot plates (Stuart®), flask (Pyrex®), ovens (Froilabo $®)$, magnetic stirrer (Stuart $\AA$ ), $\mathrm{pH}$ meter, measuring pipette (Pyrex $®$ ), modified pletismometer, rotary vacuum evaporator (Rotavapor, Buchi®), analytical scales (Precisa XB $220 A \AA$ ), and viscometer (Rion Rotor Viscotester VT04®).

The materials used in this study include Xestospongia Sp. obtained from Soropia sea waters, Konawe Regency, Southeast Sulawesi, purified water, Carbopol 940 (Intraco), 96\% Ethanol (technical), Galtaren $®$ gel (I\% Diclofenac Sodium), Green tea oil, Filter paper, Methyl paraben, $0.9 \% \mathrm{NaCl}$, Propylene glycol, Triethanolamine (TEA), and $\lambda$-Carrageenan $1 \%$.

\section{Methods}

Extraction

Sample Sponge Xestospongia Sp. obtained from the sea of Soropia, Konawe Regency, Southeast Sulawesi. Extraction was done by maceration using $96 \%$ solvent. Maserate obtained was then concentrated with a rotary vacuum evaporator at a maximum temperature of $60^{\circ} \mathrm{C}$ until a thick extract was obtained.

\section{Gel Formulation}

Gel formula for the ethanol extract of Xestospongia sp. made as much as $100 \mathrm{~g}$ with variations in extract concentrations of $0.02 \%, 0.03 \%$ and $0.04 \%$. The formula design can be seen in Table I.

Table I. Gel formulation

\begin{tabular}{|c|c|c|c|c|c|}
\hline \multirow{2}{*}{ Materials } & \multirow{2}{*}{ Function } & \multicolumn{4}{|c|}{ Formula \% (b/b) } \\
\hline & & F0 & $\mathrm{FI}$ & FII & FIII \\
\hline $\begin{array}{l}\text { Extract of } \\
\text { Xestospongia sp }\end{array}$ & $\begin{array}{l}\text { Active } \\
\text { compound }\end{array}$ & - & 0,02 & 0,03 & 0,04 \\
\hline Carbopol 940 & Gel base & $\mathrm{I}$ & $\mathrm{I}$ & $\mathrm{I}$ & $\mathrm{I}$ \\
\hline Triethanolamine & Stabilizer & 0,5 & 0,5 & 0,5 & 0,5 \\
\hline Propylene glycol & Humectant & 10 & 10 & 10 & 10 \\
\hline Methyl paraben & Preservative & 0,2 & 0,2 & 0,2 & 0,2 \\
\hline Green tea oil & Flavor & 0,05 & 0,05 & 0,05 & 0,05 \\
\hline Purified water & Carrier/solvent & $\begin{array}{l}\text { Ad } \\
100\end{array}$ & $\begin{array}{l}\text { Ad } \\
100\end{array}$ & $\begin{array}{l}\text { Ad } \\
100\end{array}$ & $\begin{array}{l}\text { Ad } \\
100\end{array}$ \\
\hline
\end{tabular}

Preparation of Xestospongia Sp. ethanol extract gel. starting with preparing tools and materials then each ingredient is weighed according to the calculations stated in the formula design. Carbopol is dispersed in warm water using a magnetic stirrer until it is homogeneous above the water bath at a temperature 
of $70-80^{\circ} \mathrm{C}$. Next to neutralize carbopol, add triethanolamine and stir again until a clear gel period is formed. After that, a number of extracts and methyl paraben were added which had been dissolved with propylene glycol and homogenized. Green tea oil is included when the mixture has been homogeneous according to the specified concentration.

\section{Gel Stability Test}

Stability evaluation is carried out by the cycling test method. The gel is stored at $4^{\circ} \mathrm{C}$ for 24 hours then released and placed at $40^{\circ} \mathrm{C}$ for 24 hours, this treatment is one cycle and carried out in six cycles. The parameters used were organoleptic test, $\mathrm{pH}$ test, viscosity test, dispersion test and homogeneity test to determine the stability of gel preparations both before the cycling test and after the cycling test.

\section{Organoleptic Gel Test}

Organoleptic observations can be assessed from the texture of the preparation including changes in color and gel odor. Observations were made on the newly created and stored gel (Sharon et al., 20I3). A stable gel must show the same character in the same color and smell before and after accelerated storage conditions (Pakki et al., 2009).

\section{PH Gel Test}

$\mathrm{PH}$ testing was carried out using a $\mathrm{pH}$ meter by means of a gel preparation weighed I $g$ then dissolved with 10 $\mathrm{mL}$ of distilled water and stirred until evenly distributed. After that the $\mathrm{pH}$ meter is dipped into the solution and the results are recorded (Saraung et al., 2018).

\section{Gel Viscosity Test}

The viscosity of the formulation is determined by Rion Rotor Viscotester VT-04 using spindle no. 3. The gel is inserted in the cup glass, then the spindle is dipped in the gel not to touch the container. Then the viscometer was turned on and it was seen what scale was designated (Aswal et al., 2013). A good semisolid preparation has a viscosity value of $50 \mathrm{dPa}$.s to 400 dPa.s (Garg et al., 2002).

\section{Gel Spread Test}

Spread test is done to ensure even distribution of gel when applied to the skin which is done as soon as the gel is made. The gel is weighed as much as $0.5 \mathrm{~g}$ then placed in the middle of a scale round glass. On top of the gel is put another round glass or other transparent material and ballast so that the weight of round glass and ballast $150 \mathrm{~g}$, let stand a minute, then note the spread diameter. Good gel spread between $5-7 \mathrm{~cm}$ (Mappa et al., 2013).

\section{Gel Homogeneity Test}

Homogeneity tests were carried out to see the homogeneity of the preparations made. The test is done by applying a gel on a piece of glass or other transparent material that is suitable, the preparation must show a homogeneous arrangement and no coarse grain is seen (Ministry of Health of the Republic of Indonesia, 1995).

\section{Grouping and Acclimatization of Test Animals}

Test animals were grouped into five groups where each group consisted of five test animals. Thirty healthy mice (20-30 g) were selected for this study. Mice were fed and drunk then acclimatized for a week before conducting the experiment.

Making Inflammation Indicators

A total of $0.1 \mathrm{~g}$ carrageenan in the form of $1 \%$ carrageenan solution made by weighing and then put in a $10 \mathrm{~mL}$ volumetric flask and then filled with a physiological solution of sodium chloride $(\mathrm{NaCl}) 0.9 \%$, to the marking line. Then incubate at $37^{\circ} \mathrm{C}$ for 24 hours (Sujono et al., 20I2).

In Vivo Antiinflammatory Test on Male White Mice White mice (Mus musculus) were grouped into five groups consisting of the positive control (diclofenac sodium gel), negative controls (gel without active ingredients), and the test group (three concentrations of gel extract of Xestospongia sp.) Ethanol extract. 
Mice were fasted for \pm 18 hours before testing and drinking water was still given. On the day of testing, each animal is weighed and marked on its left ankle, then the volume of the left leg of the mice is measured by dipping the leg of the mouse into the pletismometer to the mark boundary and recording the initial volume (Vo), which describe the volume of the foot before being treated. Then each mouse leg is subplanted with $0.1 \mathrm{~mL}$ of $\mathrm{I} \%$ carrageenan suspension. One hour after injecting carrageenan suspension, each group was treated topically according to the group. After 60 minutes of giving an anti-inflammatory gel, the volume of the left leg of the mouse is measured again with a pletismometer. Changes in the level of swelling that occurs is recorded as the volume of the left foot of the mouse $(\mathrm{Vt})$. Measurements are carried out every 60 minutes for 360 minutes.

\section{Data Analysis}

Percentage of inflammation can be calculated by the formula below (Kosala et al., 2018):

Percent inflammation $=(\mathrm{Vt}-\mathrm{Vo}) / \mathrm{Vo} \times 100 \%$

Where :

$\mathrm{Vt}=$ Inflammation volume after time $\mathrm{t}$

Vo = Initial volume of mice feet

Percent inhibition of inflammation is calculated by the formula below:

Percent inflammation inhibition $=(a-b) / a \times 100 \%$ Where :

a $=$ Percent of inflammation in the average negative control group

b = Percentage of inflammation of the average group treated with the test material or comparison drug.

\section{RESULTS AND DISCUSSION}

\section{Extraction}

Xestospongia Sp. which was used was obtained from the sea waters of Soropia, Konawe Regency, Southeast Sulawesi. Xestospongia Sp. which is used as much as 5.3 $\mathrm{kg}$. The results of the maceration process using $96 \%$ ethanol solvent, obtained as much as $205.28 \mathrm{~g}$ thick extract with the yield of $3.87 \%$.

Organoleptic Gel Test

Observations of organoleptic preparations for Xestospongia sp. Gel in Table 2 can be seen that the concentration gel formula $0 \%, 0.02 \%, 0.03 \%$, and $0.04 \%$ did not show changes before and after the cycling test. Organoleptic test gel dosage forms both before and after cycling test on all formulas showed the form of semisolid gel and the absence of phase separation, this was due to the active substance and gel base homogeneously and the amount of gelling agent sufficient to stabilize the gel (Wathoni et al., 2009). The organoleptic test for color showed the intensity of the color of the gel preparation which increased with increasing concentration of the extract on the preparation. The color test results before and after the cycling test showed stable results which were marked by no change in color on all formulas. Organoleptic tests for odor before and after cycling test showed stable results with a distinctive odor from green tea flavoring.

Table 2. Observations of organoleptic gel preparations

\begin{tabular}{|c|c|c|c|c|}
\hline $\begin{array}{l}\text { Concentration } \\
\text { of Extract (\%) }\end{array}$ & Observation & Form & Color & Odor \\
\hline 0 & $\begin{array}{l}\text { Before } \\
\text { cycling } \\
\text { After } \\
\text { cycling }\end{array}$ & $\begin{array}{l}\text { Semisolid } \\
\text { gel } \\
\text { Semisolid } \\
\text { gel }\end{array}$ & $\begin{array}{l}\text { White } \\
\text { (clear) } \\
\text { White } \\
\text { (clear) }\end{array}$ & $\begin{array}{c}\text { Typical } \\
\text { greentea } \\
\text { Typical } \\
\text { greentea }\end{array}$ \\
\hline 0,02 & $\begin{array}{l}\text { Before } \\
\text { cycling } \\
\text { After } \\
\text { cycling }\end{array}$ & $\begin{array}{l}\text { Semisolid } \\
\text { gel } \\
\text { Semisolid } \\
\text { gel }\end{array}$ & $\begin{array}{l}\text { Rather } \\
\text { yellow } \\
\text { Rather } \\
\text { yellow }\end{array}$ & $\begin{array}{c}\text { Typical } \\
\text { greentea } \\
\text { Typical } \\
\text { greentea }\end{array}$ \\
\hline 0,03 & $\begin{array}{l}\text { Before } \\
\text { cycling } \\
\text { After } \\
\text { cycling }\end{array}$ & $\begin{array}{l}\text { Semisolid } \\
\text { gel } \\
\text { Semisolid } \\
\text { gel }\end{array}$ & $\begin{array}{l}\text { Rather } \\
\text { yellow } \\
\text { Rather } \\
\text { yellow }\end{array}$ & $\begin{array}{c}\text { Typical } \\
\text { greentea } \\
\text { Typical } \\
\text { greentea }\end{array}$ \\
\hline 0,04 & $\begin{array}{l}\text { Before } \\
\text { cycling } \\
\text { After } \\
\text { cycling }\end{array}$ & $\begin{array}{l}\text { Semisolid } \\
\text { gel } \\
\text { Semisolid } \\
\text { gel }\end{array}$ & $\begin{array}{l}\text { Rather } \\
\text { yellow } \\
\text { Rather } \\
\text { yellow }\end{array}$ & $\begin{array}{c}\text { Typical } \\
\text { greentea } \\
\text { Typical } \\
\text { greentea }\end{array}$ \\
\hline
\end{tabular}

PH Gel Test

As shown in Figure I, after the cycling test there was an increase in $\mathrm{pH}$. This is due to one of the additives in the gel preparation which is propylene glycol. 
According to Rowe et al (2009), propylene glycol at low temperatures will remain stable, but at high temperatures, propylenglycol will be oxidized to propionaldehyde, lactic acid, pyruvic acid, and acetic acid. The oxidation process of propylene glycol can cause an increase in $\mathrm{pH}$ of the gel preparation. However, the range of $\mathrm{pH}$ values before and after cycling test is still within safe limits for topical preparations.

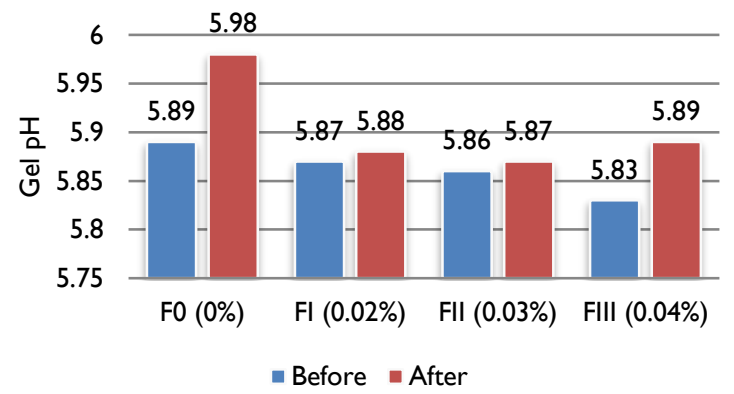

Figure I.PH gel before and after cycling test

\section{Gel Viscosity Test}

The gel viscosity test results as shown is Figure 2 indicated that after cycling test there was an increase in viscosity. This could be due to a case hardening event that would make the preparation surface dry, due to the evaporation of water on the preparation. If the relative humidity of the air outside is lower than the relative humidity of the material, then the material will vaporize the water it contains. High water concentrations in gel preparations allow desorption, where water in the gel will evaporate which causes the gel to become denser so that the viscosity increases.

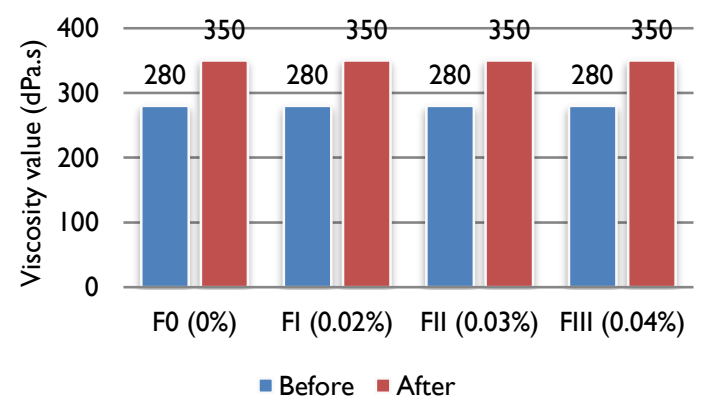

Figure 2. Gel viscosity before and after cycling test Gel Spread Test
The results of the scattered power test results as shown in Figure 3 show that the spread of the gel will be greater with the increase in the amount of concentration of the extract added. But there was a decrease in the spread of gel after cycling test, this was in accordance with the increase in gel viscosity. The viscosity value is inversely proportional to the spread value of a gel preparation, so that if the gel has a high viscosity value, the value of the spreadability of the gel will be low. Based on this, all gel preparations did not meet the requirements for the semi-solid stock spread parameters of $5-7 \mathrm{~cm}$ (Garg et al., 2002).

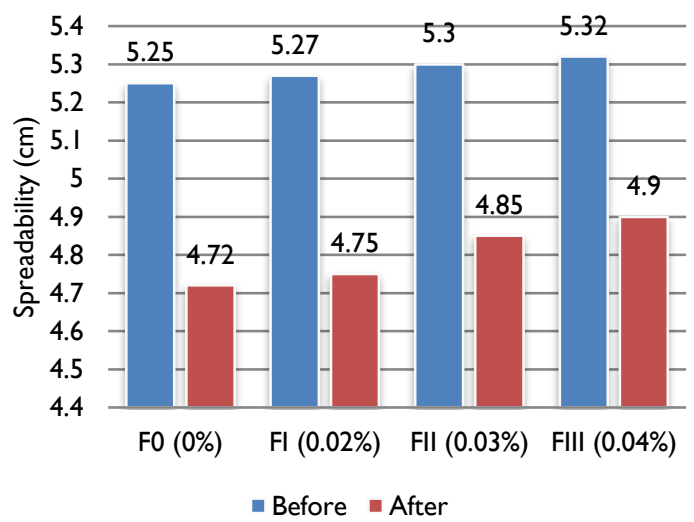

Figure 3. Gel spreadibility before and after cycling test

\section{Gel Homogeneity Test}

The results of the observations on the gel homogeneity test of Xestospongia Sp. showed that the gel with extract concentrations of $0 \%, 0.02 \%, 0.03 \%$, and $0.04 \%$ showed no lumps or coarse grains as can be seen in Table 3. This shows that the preparations made have a homogeneous arrangement, both before and after the cycling test.

Table 3. The observation of gel homogeneity

\begin{tabular}{|c|c|c|}
\hline \multirow{2}{*}{$\begin{array}{c}\text { Concentration of } \\
\text { Extract (\%) }\end{array}$} & \multicolumn{2}{|c|}{ Homogeneity } \\
\hline & Before cycling test & After cycling test \\
\hline 0 & $\begin{array}{l}\text { Homogeneous, } \\
\text { no coarse grain }\end{array}$ & $\begin{array}{l}\text { Homogeneous, } \\
\text { no coarse grain }\end{array}$ \\
\hline 0.02 & $\begin{array}{l}\text { Homogeneous, } \\
\text { no coarse grain }\end{array}$ & $\begin{array}{l}\text { Homogeneous, } \\
\text { no coarse grain }\end{array}$ \\
\hline 0.03 & $\begin{array}{l}\text { Homogeneous, } \\
\text { no coarse grain }\end{array}$ & $\begin{array}{l}\text { Homogeneous, } \\
\text { no coarse grain }\end{array}$ \\
\hline 0.04 & $\begin{array}{l}\text { Homogeneous, } \\
\text { no coarse grain }\end{array}$ & $\begin{array}{l}\text { Homogeneous, } \\
\text { no coarse grain }\end{array}$ \\
\hline
\end{tabular}


In Vivo Antiinflammatory Test on Male White Mice

Antiinflammation is the term for agents / drugs that work against or suppress the inflammatory process. The method of testing the anti-inflammatory effects of a drug candidate based on the ability of the test drug reduces or suppresses the degree of udema in experimental animals. The gel formula which has been tested for stability is then tested for anti-inflammatory effects on white male mice test animals. Male sex is chosen so that the inflammatory response is not influenced by the estrogen hormone (Sativa et al., 20I4).

Before testing, the test animals were acclimatized for a week with the aim of giving the animals time to adapt to the new environment. Furthermore, each mouse that will be used, fasted for approximately 18 hours and only given a drink, this is intended to avoid the possibility of the influence of food on the effect of the gel to be tested so that the gel given can provide a good anti-inflammatory effect.

The testing of antiinflammatory activity in this study was by inducing $\lambda$-carrageenan $1 \%$ on the left foot of the mice. Based on the research that has been done that after carrageenan administration, the legs of mice are inflamed. Carrageenan induction results in the formation of inflammation consisting of two phases, I2 hours after carrageenan injection, causing trauma due to inflammation caused by carrageenan. In the first phase there is the release of serotonin and histamine to the site of inflammation and an increase in prostaglandin synthesis in damaged tissue. In the second phase prostaglandin release occurs and is mediated by bradykinin and leukotriene (Manurung \& Sumiwi, 2016). Inflammation that occurs in the legs of mice is seen with the onset of swelling and redness which is a feature of inflammation. This can be seen by increasing the volume of mice feet measured by a modified pletismometer. This method with the pletismometer tool was chosen because it has advantages in terms of implementation that is easier and simpler (Duarte et al., 20I2).
In this study the effectiveness of mice was carried out by comparing Xestospongia Sp. gels with preparations of diclofenac sodium gel (Galtaren $\AA$ ) as a positive control and gel without extract as a negative control. Gel formulas with various extract concentrations were $0.02 \%, 0.03 \%$, and $0.04 \%$ used as test drug ingredients.

The analysis was performed on the results of changes in the volume of mice feet starting 60 minutes to 360 minutes or for six hours after carrageenan injection subplantar. From changes in the volume of mice feet can be calculated percent inflammation and percent inhibition of inflammation of mice. The results of percent inflammation in each treatment group and control group can be seen in Figure 4.

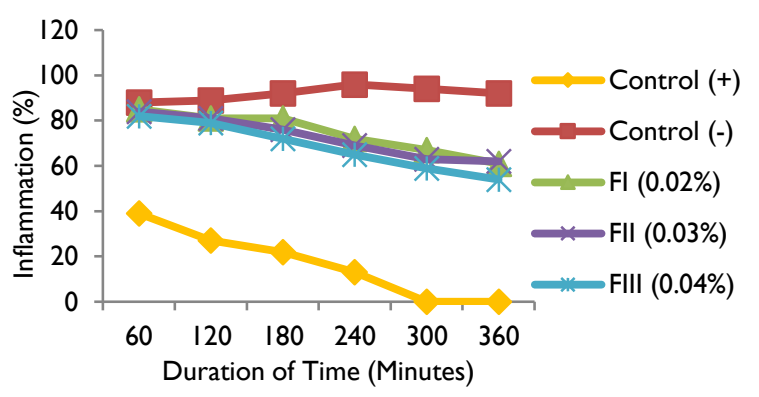

Figure 4. The average percentage of inflammation in the legs of mice

Figure 4 shows that there was a different decrease in inflammation in each treatment group and the control group. Giving the $\mathrm{FI}$ group gel $(0.02 \%)$ experienced a decrease in inflammation in the $240^{\text {th }}$ minute. Whereas in the FII group $(0.03 \%)$ and FIII $(0.04 \%)$ experienced the same decrease in inflammation starting in the $180^{\text {th }}$ minute. In contrast to positive controls where the decrease in inflammation was greater than the test group, it occurred in the $60^{\text {th }}$ minute. The graph data above shows that the FI group (0.02\%), FII (0.03\%), and FIII (0.04) takes longer than 360 minutes to cure inflammation. The percent value of the inflammatory barrier for each measurement time can be seen in Figure 5. 


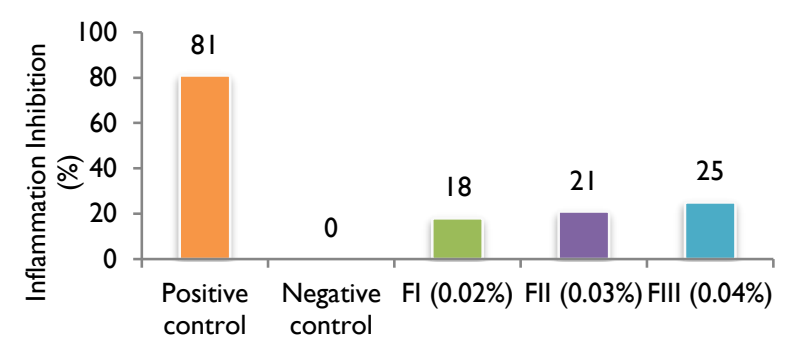

Figure 5. The average percentage of inhibition of inflammation of the legs of mice

Figure 5 shows that all treatment groups experienced a decrease in edema except negative controls that did not contain extracts. This is due to negative carrageenaninduced controls only given base gel treatment so that there is no healing stimulation to reduce edema and the edema response relies solely on the natural immune system of mice. This causes the edema to continue to enlarge, so the percentage reduction in edema is $0 \%$.

Based on the Kruskal Wallis test on mice edema volume, the gel showed that the extract of the ethanol extract Xestospongia Sp. there were significant differences between the negative control group with positive control, FI (0.02\%), FII (0.03\%), and FIII (0.04\%) with a significant value $(P<0.05)$ at the 60 th minute to 360 minutes, so it can be concluded that these four groups have anti-inflammatory activity in inhibiting edema in the feet of mice compared to negative controls. It needs to be continued with the Mann Withney $U$ test to find out whether there are significant differences between categories.

Based on the average inflammatory rate, the $\mathrm{FI}$ group (0.02\%), FII (0.03\%), and FIII $(0.04 \%)$ had a greater average inflammatory value with a lower inhibition compared to the control positive. In the statistical test FI (0.02\%), FII (0.03\%), and FIII (0.04\%) differed significantly from positive controls with significant values $(P<0.05)$. This shows that $\mathrm{FI}(0.02 \%)$, FII $(0.03 \%)$, and FIII $(0.04 \%)$ have lower antiinflammatory activity than positive controls positive control. Statistical tests on all formulas showed $\mathrm{FI}(0.02 \%)$, FII $(0.03 \%)$, and FIII
(0.04\%) there were no significant differences with significant values $(P>0.05)$, so that all formula has the same anti-inflammatory activity in inhibiting edema.

The anti-inflammatory effect is thought to be due to the activity of chemical compounds contained in Xestospongia Sp. consisting of flavonoids and sterols which are known as steroid alcohols, which are a subgroup of steroids. Steroid compounds have antiinflammatory activity by the mechanism of activating glucocorticoid receptors by increasing or decreasing the transcription process of genes involved in the inflammatory process (Luliana et al., 2017). Metabolic compounds that can inhibit inflammation are flavonoids. Flavonoids can inhibit the cyclooxygenase enzyme that plays a role in prostaglandin biosynthesis (Sativa et al., 2014) and inhibits the lipookigenase enzyme that plays a role in leukotriene biosynthesis in inflammation formation (Sukmawati et al., 20I5).

\section{CONCLUSION}

Based on the results of the research that has been obtained it can be concluded that the ethanol extract of Xestospongia Sp. can be formulated in gel preparations with concentrations of $0.02 \%, 0.03 \%$ and $0.04 \%$. The gel preparation formula is physically stable in terms of organoleptic observation, homogeneity test, $\mathrm{pH}$ and viscosity test. However, the results obtained in scattered power testing do not meet the requirements. Gel preparation from the ethanol extract of Xestospongia Sp. has an anti-inflammatory effect on each concentration and the formula which has a large antiinflammatory effect is obtained at the extract concentration of $0.04 \%$.

\section{ACKNOWLEDGEMENTS}

The author would like to thank the Ministry of Research, Technology and Higher Education Republic 
of Indonesia for funding the Penelitian Dasar Unggulan

Perguruan Tinggi 2018.

\section{REFERENCES}

Amri, M.U. 2018. Uji Aktivitas Antiinflamasi dengan Metode Stabilisasi Membran Sel Darah Merah Secara In Vitro dan Uji Toksisitas Akut Terhadap Larva Udang Artemia Salina Leach Ekstrak Etanol Spons Xestospongia Sp. Skripsi. Faculty of Pharmacy, Department of Pharmacy, Universitas Halu Oleo, Kendari.

Aswal, A., Kalra, M., Rout, A. 2013. Preparation and Evaluation of Polyherbal Cosmetic Cream. Der Pharmacia Lettre. 5(I):83-88.

Cribb, R., Ford, M. 2009. Indonesia as an archipelago: managing islands, managing the seas. In Singapore-Indonesia beyond the water's edge: managing an archipelagic state. Singapore: ISEAS-Yusof Ishak Institute.

Duarte, D.B., Vasko, M.R., Fehrenbacher, J.C. 2012. Models of Inflammation: Carrageenan Air Pouch. Current Protocols in Pharmacology. CHAPTER 5: Unit5.6.

El-Shitany, N.A., Shaala, L.A., Abbas, A.T., AbdelDayem, U.A., Azhar, E.I., Ali, S.S., van Soest, R.W., Youssef, D.T. 2015. Evaluation of the Anti-Inflammatory, Antioxidant and Immunomodulatory Effects of the Organic Extract of the Red Sea Marine Sponge Xestospongia testudinaria against Carrageenan Induced Rat Paw Inflammation. PLoS One. 10(9): e0138917.

Garg, A., Aggarwal, D, Garg, S., Singla, A.K. 2002. Spreading of Semisolid Formulation: An Update. Pharmaceutical Technology North America. 26(9):84- 105.

Hardman, J.G., Limbird, L.E. 2003. Goodman \& Gilman: Dasar Farmakologi Terapi. Ed. I0. Vol.2. Jakarta: Penerbit Buku Kedokteran EGC.

Kosala, K., Widodo, M.A., Santoso, S., Karyono, S. 2018. In vitro and In vivo Anti-inflammatory Activities of Coptosapelta flavescens Korth Root's Methanol Extract. Journal of Applied Pharmaceutical Science. 8(9):42-48.

Luliana, S., Susanti, R., Agustina, E. 2017. Uji Aktivitas Antiinflamasi Ekstrak Air Herba Ciplukan (Physalis angulata L.) terhadap Tikus Putih (Rattus norvegicus L.) Jantan Galur Wistar yang Diinduksi Karagenan. Majalah Obat Tradisional. 22(3): 199-205.

Manurung, N.R.M., Sumiwi, S.A. 2016. Aktivitas Antiinflamasi Berbagai Tanaman Diduga Berasal dari Flavonoid. Farmaka Online. |4(2): I | |- | 23.

Mappa, T., Edy, H.J., Kojong, N. 2013. Formulasi Gel Ekstrak Daun Sasaladahan (Peperomia pellucida (L.) H.B.K) dan Uji Efektivitasnya Terhadap Luka Bakar pada Kelinci (Oryctolagus Cuniculus). Pharmacon. 2(2):4955.

Marzuki, I. 2018. Eksplorasi Spons Indonesia: Seputar Kepulauan Spermonde. Makassar: Nas Media Pustaka.

Mehbub, M.F., Lei, J., Franco, C., Zhang, W. 2014. Marine Sponge Derived Natural Products between 200I and 2010: Trends and Opportunities for Discovery of Bioactives. Marine Drugs. 12(8):4539-4577.

Ministry of Health of the Republic of Indonesia. 1995. Materia Medika Indonesia Edisi VI. Jakarta: Dirjen Pengawas Obat dan Makanan.

Murniasih, T. 2003. Metabolit Sekunder dari Spons Sebagai Bahan Obat-Obatan. Oseana. 28(3):27-33.

Pakki, E., Sartini, Tayed, R., Maisarah, N.L. 2009. Formulasi dan Evaluasi Kestabilan Fisik Gel Antioksidan Ekstrak Biji Kakao (Theobroma cacao L.). Majalah Farmasi dan Farmakologi. I3(2): I-7.

Rowe, R.C., Sheskey, P.J., Quinn, M.E. 2009. Handbook of Pharmaceutical Excipients $6^{\text {th }}$. London: American Pharmaceutical Association.

Sadarun, B., Malaka, M.H., Wahyuni, Sahidin. 2018. Senyawa Steroid Spons Xestospongia sp. dari Perairan Sulawesi Tenggara, Pharmauho: Jurnal Farmasi, Sains dan Kesehatan. 4(I):26-29.

Saraung, V., Yamlean, P.V., Citraningtyas, G. 2018, Pengaruh Variasi Basis Karbopol Dan HPMC pada Formulasi Gel Ekstrak Etanol Daun Tapak Kuda (Ipomoea Pes-Caprae (L.) R. Br. dan Uji Aktivitas Antibakteri Terhadap Staphylococcus Aureus. Pharmacon. 7(3):220229.

Sativa, O., Yuliet, Y., Sulastri, E. 20I4. Uji Aktivitas Antiinflamasi Gel Ekstrak Kaktus (Opuntia elatior Mill.) pada Tikus (Rattus norvegicus L.) 
yang Diinduksi Lamda Karagenan. Natural Science: Journal of Science and Technology. 3(2):79-94.

Sayuti, N.A. 2015. Formulasi dan Uji Stabilitas Fisik Sediaan Gel Ekstrak Daun Ketepeng Cina (Cassia alata L.). Jurnal Kefarmasian Indonesia. 5(2):74-82.

Sharon, N., Anam, S., Yuliet, Y. 2013, Formulasi Gel Antioksidan Ekstrak Etanol Bawang Hutan (Eleutherine palmifolia L. Merr). Natural Science: Journal of Science and Technology. 2(3): I II-I 22.

Sujono, T.A., Patimah, R., Yuliani, R. 2012. Efek Antiinflamasi Infusa Rimpang Temu Putih (Curcuma zedoaria (Berg) Roscoe) pada Tikus yang Diinduksi Karagenin. Biomedika. 4(2): $10-17$.

Sukmawati, S., Yuliet, Y., Hardani, R. 20I5. Uji Aktivitas Antiinflamasi Ekstrak Etanol Daun Pisang Ambon (Musa Paradisiaca L.) Terhadap Tikus Putih (Rattus Norvegicus L.) yang Diinduksi Karagenan. Jurnal Farmasi Galenika (Galenika Journal of Pharmacy). I(2): I 26-I 32.

Wathoni, N., Rusdiana, T., Hutagaol R.Y. 2009. Formulasi Gel Antioksidan Ekstrak Rimpang Lengkuas (Alpinia galanga L. Wild) dengan Menggunakan Basis Aqupec 505 HV. Farmaka Online. 7(I): 15-27.

Widiyantoro, A., Destiarti, L., Kusharyanti, I., Supardi., Halim, D.G., Niwick, Willianti, V. 2012. Aktivitas Antiinflamasi Senyawa Bioaktif dari Kulit Batang Pauh Kijang (Irvingia malayana Oliv. ex. A. Benn) terhadap Tikus Putih (Rattus norvegicus) yang Diinduksi Karagenan. Kaunia: Jurnal Sains, Pendidikan Sains dan Teknologi. 8(2): I I8-126.

Wijaya, L., Saleh, I., Theodorus, T., Salni, S. 20I5. Efek Antiinflamasi Fraksi Daun Andong (Cordyline Fruticosa L) Pada Tikus Putih Jantan (Rattus norvegicus) Galur Spraque Dawley. Biomedical Journal of Indonesia. I(I): 16-24. 